\title{
A Location Intelligence System for the Assessment of Pluvial Flooding Risk and the Identification of Storm Water Pollutant Sources from Roads in Suburbanised Areas
}

\author{
Szymon Szewrański ${ }^{1, *(1)}$, Jakub Chruściński ${ }^{1}$, Joost van Hoof ${ }^{1,2}{ }^{(1)}$, Jan K. Kazak ${ }^{1}{ }^{(\mathbb{D})}$, \\ Małgorzata Świąder $^{1}$ (D), Katarzyna Tokarczyk-Dorociak ${ }^{3}{ }^{(10}$ and Romuald Żmuda ${ }^{4}$ \\ 1 Department of Spatial Economy, Faculty of Environmental Engineering and Geodesy, Wrocław University of \\ Environmental and Life Sciences, ul. Grunwaldzka 55, 50-357 Wrocław, Poland; \\ kuba.chruscinski@gmail.com (J.C.); j.vanhoof@hhs.nl (J.v.H.); jan.kazak@upwr.edu.pl (J.K.K.); \\ malgorzata.swiader@upwr.edu.pl (M.Ś.) \\ 2 Faculty of Social Work \& Education, The Hague University of Applied Sciences, Johanna Westerdijkplein 75, \\ 2521 EN Den Haag, The Netherlands \\ 3 Institute of Landscape Architecture, Faculty of Environmental Engineering and Geodesy, Wrocław \\ University of Environmental and Life Sciences, ul. Grunwaldzka 55, 50-357 Wrocław, Poland; \\ katarzyna.tokarczyk-dorociak@upwr.edu.pl \\ 4 Institute of Environmental Protection and Development, Faculty of Environmental Engineering and \\ Geodesy, Wrocław University of Environmental and Life Sciences, pl. Grunwaldzki 24, \\ 50-363 Wrocław, Poland; romuald.zmuda@upwr.edu.pl \\ * Correspondence: szymon.szewranski@upwr.edu.pl
}

Received: 8 May 2018; Accepted: 5 June 2018; Published: 7 June 2018

\begin{abstract}
The interplay of an ever-growing number of inhabitants, sprawl development, soil sealing, changes in urban traffic characteristics, as well as observed climate trends gives rise to more frequent pluvial flooding in cities, a higher run-off of water, and an increasing pollution of surface water. The aim of this research is to develop a location intelligence system for the assessment of pluvial flooding risks and the identification of storm water pollutant sources from roads in newly-developed areas. The system combines geographic information systems and business intelligence software, and it is based on the original Pluvial Flood Risk Assessment tool. The location intelligence system effectively identifies the spatial and temporal distribution of pluvial flood risks, allows to preliminarily evaluate the total run-off from roads, and helps localise potential places for new water management infrastructure. Further improvements concern the modelling of a flow accumulation and drainage system, the application of weather radar precipitation data, and traffic monitoring and modelling.
\end{abstract}

Keywords: location intelligence; pluvial flood risk assessment; road run-off management; storm water pollutant sources; green infrastructure; blue infrastructure; urban climate adaptation

\section{Introduction}

Urban growth and climate change will be the main drivers of the deterioration of water resources in the near future. These processes affect both water quality and water quantity in urbanised catchment areas [1]. As the number of inhabitants in cities is expected to keep growing, negative consequences such as urban sprawl [2-4] and soil sealing [5] will also become increasingly significant. Urbanisation will lead to additional changes in the characteristic of urban traffic, as the volume of traffic and subsequent patterns of congestion increases. As a consequence, larger amounts of pollutants will build up on road surfaces [6]. 
Simultaneously, global climate change is expected to induce a transformation in pluvial spatiotemporal distribution and magnitudes [7-9]. The increase of high-intensity rainfall frequencies and patterns is predicted [10]. The interplay of growing impervious areas with extreme and high rates of precipitation will lead to the occurrence of local pluvial floods, and, consequently, higher surface water run-off [11-14]. Increasing flooding trends result in evenly increasing trends in economic losses [15]. In the future, pluvial floods could generate more cumulative damage than fluvial flooding events [16]. The direct and indirect impacts of extreme weather include losses in economic terms [17], the damaging and destruction of private buildings and urban infrastructure [18], the loss of human lives and the degradation of safety [19], and the deterioration of water quality [20].

The water quality on the watershed scale is notably related to the percentage of the impervious surface area [21]. Road dust deposit is one of the main sources of urban pollutants. Because of low leaching ratios, these pollutants are mainly transported in particulate forms [22]. Sealed surfaces provide a sink for road sediments, which tend to accumulate during dry periods. After each dry period, the built-up urban sediment and bound pollutants get detached and washed off by rainfall [23]. The wash-off process is either limited by road-deposited sediments or limited by transport [24], depending on the road's slope, the geometry and layout of curbs, and street sweeping [25], as well as the road surface's material (i.e., asphalt, concrete), and its characteristics (i.e., its roughness and texture influence on run-off quality) [26]. Storm water run-off from traffic areas contains zinc $(\mathrm{Zn})$, copper (Cu), lead $(\mathrm{Pb})$, chromium $(\mathrm{Cr})$, suspended solids, as well as Polychlorinated Biphenyls (PCBs), Petroleum Hydrocarbons (PH), Polycyclic Aromatic Hydrocarbons (PAHs), and many others, which can degrade and pollute surface waterways [27-30]. Moreover, run-off contains readily soluble salts of potassium $(\mathrm{K})$, cadmium $(\mathrm{Ca})$, sodium $(\mathrm{Na})$, magnesium $(\mathrm{Mg})$, chloride $(\mathrm{Cl})$, and sulfate $\left(\mathrm{SO}_{4}\right)$ [31]. There is a total of 1100 identified organic pollutants, which can be potentially transferred from road-related sources to the environment.

The mean concentrations of pollutants in run-off waters are dependent on rainfall characteristics and land use. Rainfall depth, mean intensity, and max 5-min intensity play a crucial role in so-called pollutant loading [32]. British research on integrated urban wastewater systems, which was carried out using the SIMBA5 simulation tool, showed that rainfall depth has a more significant impact on the surface water quality than the rainfall intensity [1]. Then there is the effect of first flush, which described the observation of higher concentrations of pollutants in run-off water at the beginning of a storm event [33].

There is a strong correlation between high traffic intensities and the levels of pollutants. Berndtsson [34] recorded particularly high rates of heavy metals and total phosphorus (P) in storm water in places where traffic intensity reached 7000 vehicles per day. Numerous studies on rainwater pollutants that have washed off the roads include the evaluation of seasonal variability of physical and chemical parameters [35], research on the partitioning and mobilising of inorganic chemicals and trace metals [36], analyses of particle size distribution [37], biotoxicity assessments [38], as well as impact assessments on the immune function of aquatic biota [39], and the examination of spills of hazardous compounds during traffic accidents [40].

As the pluvial flood risk (understood as a combination of hazards and damages) is forecast to increase in the future [41,42], cities and suburbs should become more resilient and adapted to new climatic and socio-economic conditions [43]. For a rational decision-making process in adaptation and spatial planning, the assessment of pluvial flood risk is essential [44]. Studies on the spatiotemporal dynamics of pollutants in run-off waters, as well as information on urban patterns and drainage systems, should help urban designers and decision makers to mitigate the rising impacts of urbanisation on aquatic ecosystems [45]. One of the challenges is to recognise the major pathways of heavy metals to the build-up on roads in order to protect the receiving aquatic environment [46].

Low-Impact Development (LID) and Green Infrastructure (GI) are effective measures to collect, infiltrate, and remove heavy metals, solid particles, and other pollutants loading from storm water run-off [47]. Among the most effective LID and GI practices are green roofs [48], permeable or porous 
pavements, rain gardening [49], application of water-absorbing geocomposites [50], and bioretention systems [8]. Waste waters derived from small settlements or produced in service areas located along major roads can be treated using aquatic plants and hydroponic systems [51,52]. At the catchments scale, water pollution removal can be provided in so-called Nature-Based Treatment Systems (NBTS) [53].

Locating and designing flood management facilities can be supported by modelling, risk evaluation, as well as decision making and monitoring systems. It is necessary to properly estimate their capacity in relation to changing water levels $[54,55]$. Decisive information could be complemented by simulations of land use changes and land take impact assessments $[56,57]$ or the indictor-based spatial multivariate analysis [57,58].

Yin et al. [59] proposed an integrated methodology, which incorporates flood inundation modelling, traffic management, and risk assessment, to measure the impact of pluvial flash floods on intra-urban road networks in the city centre of Shanghai, China. They used high-resolution Flood Map (2D hydro-inundation modelling) to simulate overland flow and flood inundation for various flood return periods. Shorshani et al. [60] developed an original modelling tool that integrates simulations of traffic rates, gas emissions, and air and storm water pollution: they used a combined methodology of COPERT4, Polyphemus, and the United States Environmental Protection Agency Storm Water Management Model (USEPA SWMM) in order to predict the road traffic impact on the contamination of surface waters. The SWMM was also applied in the Urban Rainfall-Runoff Water Quality model developed by Gong et al. [61], which was used to simulate the load of suspended solids washed off a university campus in Beijing, China. In some studies [12,49,62], the SWMM is used to evaluate the effects of LID on run-off reduction. Fraga et al. [27] developed their own MEDUSA (Modelled Estimates of Discharges for Urban Stormwater Assessments) modelling framework. This tool calculates the pollutant build-up and wash-off from impervious surfaces such as roofs, roads, and car parks. Simulations can be made of single rain events, different land use patterns, and rainfall parameters. In addition, Trenouth and Gharabaghi [63] applied artificial neural networks to predict the mean concentration and the mean daily unit area load of highway pollutants. They accounted for traffic characteristics as well as meteorological factors of severe rainfalls, and their results supported the design of roadside ditch treatment systems and helped protect sensitive aquatic environments. Chen et al. [8] developed a planning support model that combines rainwater management with Computer-Aided Design (CAD) software. Finally, the City Catchment Analysis Tool (CityCAT) by Bertsch et al. [64] can be applied for better urban drainage designing and locating storm drain inlets. Overall, integrated systems combine pluvial flood risk mapping with water management tasks, as well as the economic effectiveness of flood control and adaptation measures [14].

The state of the art of flooding risk assessment, pollutant transfer modelling as well as planning and designing support systems shows some gaps in knowledge and practice:

Research on pluvial events loss modelling and quantification is relatively rare [15,16];

Modelling should take spatiotemporal variability from rainfall and flooding distribution into consideration [42];

There is a lack of support tools for designers and policy-makers, which would benefit landscape management [8];

Decision support systems should be developed for larger areas and should provide an assessment of the capability of new adaption practices [49].

\section{Aims}

The aim of this research is to develop the location intelligence system which will support:

- Pluvial flooding risk assessment;

- Spatial identification of potential diffuse road pollutant sources,

- Locating and dimensioning of the GI facilities. 
The main assumption was that the system should be user-friendly and accessible for non-technical experts. Policy makers, architects, and designers are expected to use the system without any extra computer or database operational skills. This study is a continuation of previous research presented by Szewrański et al. [65].

\section{Methodology}

The methodological framework encompasses a combination of software integration of location intelligence systems, spatial data geoprocessing and weather data extraction, field inspections, and finally pluvial flood risk assessment and testing of the location intelligence system.

\subsection{Location Intelligence System}

The core element of location intelligence system is the original Pluvial Flood Risk Assessment (PFRA) tool, developed for supporting the urban adaptation to climate change [65]. A workflow model that was coded using the Python language is a combination of Geographic Information System (GIS) geoprocessing and land use spatial assessment, elevation and hydrologic analyses, as well as the application of climate change modelling and weather forecasting. The model can be used for various area sizes. Modelling results are stored in a tabular, spatiotemporal database, and are connected to a business intelligence system, responsible for visual data exploration (Figure 1). The location intelligence system is based on actively connected ArcGIS and Tableau software [66,67].

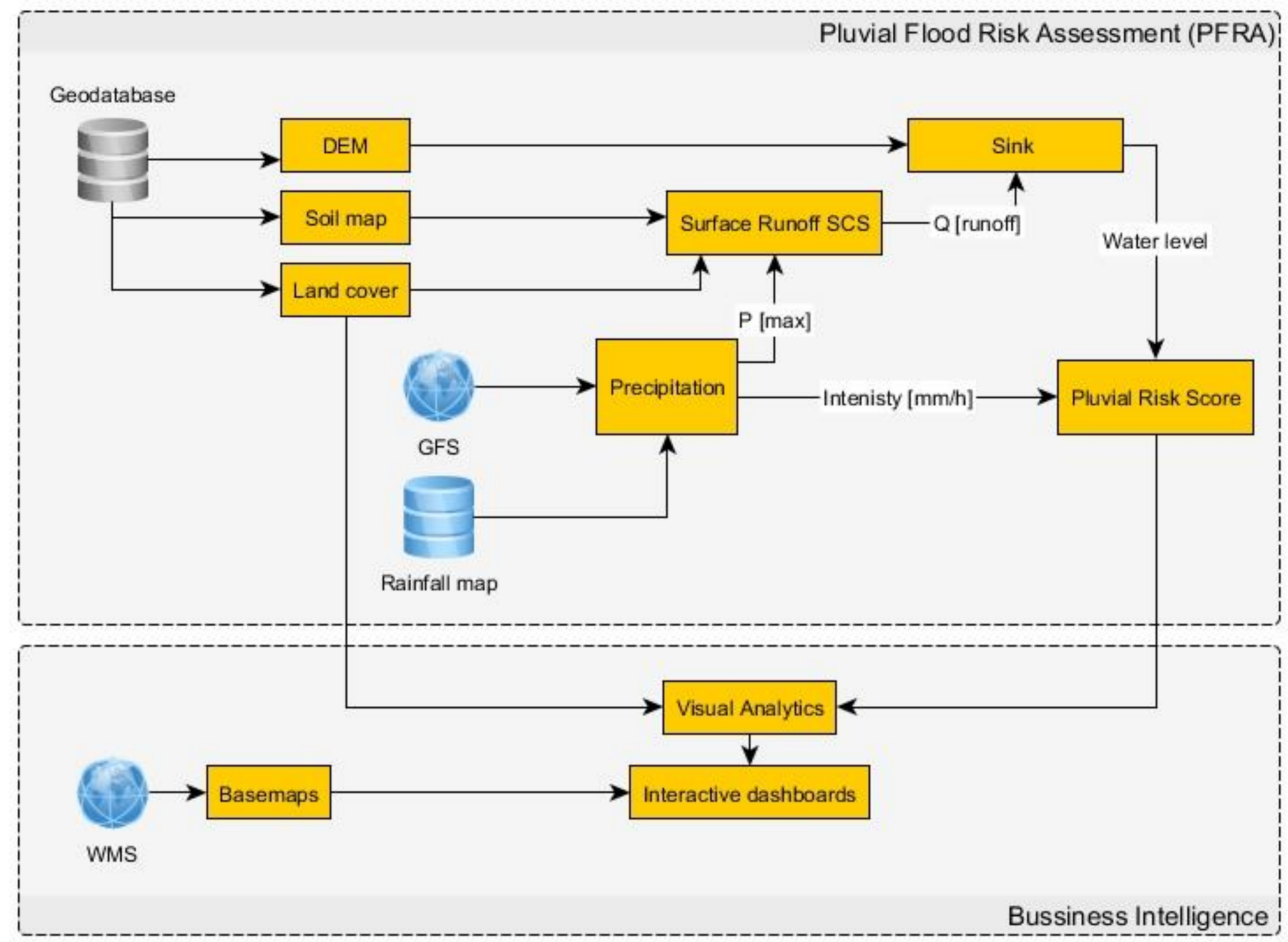

Figure 1. A schematic overview of the location intelligence system.

\subsubsection{Data}

Digital elevation data were received from Light Detection and Ranging (LiDAR) measurements. The spatial resolution of the Digital Elevation Model (DEM) used in the model was $1.0 \mathrm{~m} \times 1.0 \mathrm{~m}$. Soil data were retrieved from administrative databases based on an Institute of Soil Science and Plant Cultivation (IUNG) map with a reference scale of 1:25,000. Land cover data were taken from the Urban Atlas repository. The location intelligence system operates based on the Global Forecast System (GFS) produced by the National Centers for Environmental Prediction (NCEP). The rainfall data subsets 
stored in grib2 files are made available in time steps of $3 \mathrm{~h}$ each. In this study, the GFS dataset was used for the 24 and 25 July 2017. Weather data were analysed and visualised with use of zyGrib software. Field inspections were carried out in order to discover manmade changes to the watershed and to examine the hydrographic system.

\subsubsection{Pluvial Flood Risk Assessment}

Spatial data were processed with GIS tools in order to obtain pluvial flood risk distribution. Analytical workflow, assumptions and limitations were described in detail by Szewrański et al. [65]. The most important limitation at this stage was the model does not incorporate the underground storm water system. The run-off volume was calculated with use of Soil Conservation Service Curve Number (SCS-CN) hydrological model [68]. Calculations were provided for different land use scenarios and values of surface permeability. The SCS-CN methodology incorporates the water balance formula, based on the main assumption that the ratio of surface run-off to the total precipitation equates the ratio of actual infiltration to the potential maximum retention. The SCS-CN model is expressed by Equation (1).

$$
Q=\frac{(P-I)^{2}}{P-I+S}
$$

where:

$$
\begin{aligned}
& Q \text {-direct run-off }[\mathrm{mm}] \\
& P \text {-total precipitation }[\mathrm{mm}] \\
& \text { - } \text {-initial abstraction }[\mathrm{mm}] \\
& S \text { - potential maximum retention }[\mathrm{mm}]
\end{aligned}
$$

The potential maximum retention can be calculated with Equation (2).

$$
S=25.4\left(\frac{1000}{C N}-10\right)
$$

where $C N$ is the curve number related to the soil characteristics, land cover and the antecedent moisture condition.

The SCS methodology can be successfully applied in Polish hydrometeorological conditions as shown by previous research [69]. Basing on methodology applied by Ignar [70], the soils were classified into four groups of different infiltration capabilities : A, the highest; $B$, above the mean; $C$, below the mean; and D, the lowest. The areas covered by these groups were delimited. A soil map was combined with the Urban Atlas map: that way, $\mathrm{CN}$ values could be assigned to different land covers and soil classes with the use of US Department of Agriculture (USDA) tables [68].

The location and extent of impounded areas were evaluated with use of the hydrologic sink geoprocessing tools.

The Pluvial Risk Score (PRS) was calculated as a multiplication of hazard, vulnerability, and exposure values. The hazard assessment incorporates the amount of effective precipitation and the level of impounding water. The mean hazard varies from 0 to 100 points. When the rainfall exceeds $25.0 \mathrm{~mm}$, the hazard value equals 100 points. The vulnerability assessment is based on the percentage rates of damage to buildings and their interiors. Based on a review of the literature [16], it was assumed that for every $1.0 \mathrm{~cm}$ of additional flood water, an increase in the damage of buildings of $3.37 \%$ is observed, and an increase of $5.88 \%$ for interior equipment. The exposition valuation is simplified: for each flooded area, the parameter equals 100. The final thus PRS varies from 0 to 100 . The maximum valid value for rainfall is $400 \mathrm{~mm}$. 


\subsubsection{Business Intelligence}

Spatial and temporal data processed in GIS were stored in a geodatabase, which was directly connected to a business intelligence tool. All operations on data files, such as filtering, extraction, aggregation, and table calculation, can be provided within the graphical interface. The main output of the system was an interactive and dynamic dashboard, which contained land use information, pluvial flood risk maps, as well as effective rainfall and a spatiotemporal distribution of the surface runoff.

\subsection{Study Site}

The location intelligence system was tested for use in the suburban settlements of the city of Wrocław, Poland. As one of the largest and most rapidly developing Polish cities [71], Wrocław is impacted by uncontrolled suburbanization [72,73], farmland degradation [74,75], and landscape deformation $[76,77]$. As a consequence, there are many negative effects of rapid urbanization, such as rising low emission and environmental pollution by traffic flow [78-80], changes in biodiversity and ecosystem services [81], thermal stress [82,83], as well as numerous economic and social implications $[84,85]$. Wrocław and its suburbs are mostly lying in the valleys and floodplains of the River Odra and its tributaries. This region is affected by regular pluvial and fluvial floods events [86-90]. Simultaneous hydroclimate changes and urbanisation processes generate new challenges, that should be managed within the framework of strategic adaptation planning and decision making [91-93].

The experimental study site was located in the village of Kamieniec Wrocławski $\left(51^{\circ} 04^{\prime} 43.7^{\prime \prime} \mathrm{N}\right.$ $\left.17^{\circ} 10^{\prime} 36.0^{\prime \prime} \mathrm{E}\right), 10 \mathrm{~km}$ from the centre of Wrocław (Figure 2). The total surface area of the study site was $0.85 \mathrm{~km}^{2}$. A discontinuous urban settlement that was characterised by a soil sealing level of $50-80 \%$ occupied $28.7 \%$ of the total area. A continuous urban fabric with more than $80 \%$ of impervious surfaces shares $19.5 \%$ of the total area. Arable lands took up $21.4 \%$, and pastures occupied $18.6 \%$ of the land. About $6.1 \%$ of the site was occupied by roads and associated lands, whereas industrial, commercial, and public places took up 2.3\%. Grounds covered by water made up less than $1.0 \%$ of the area. The total length of watercourses located in the study site is approximately $3400 \mathrm{~m}$.

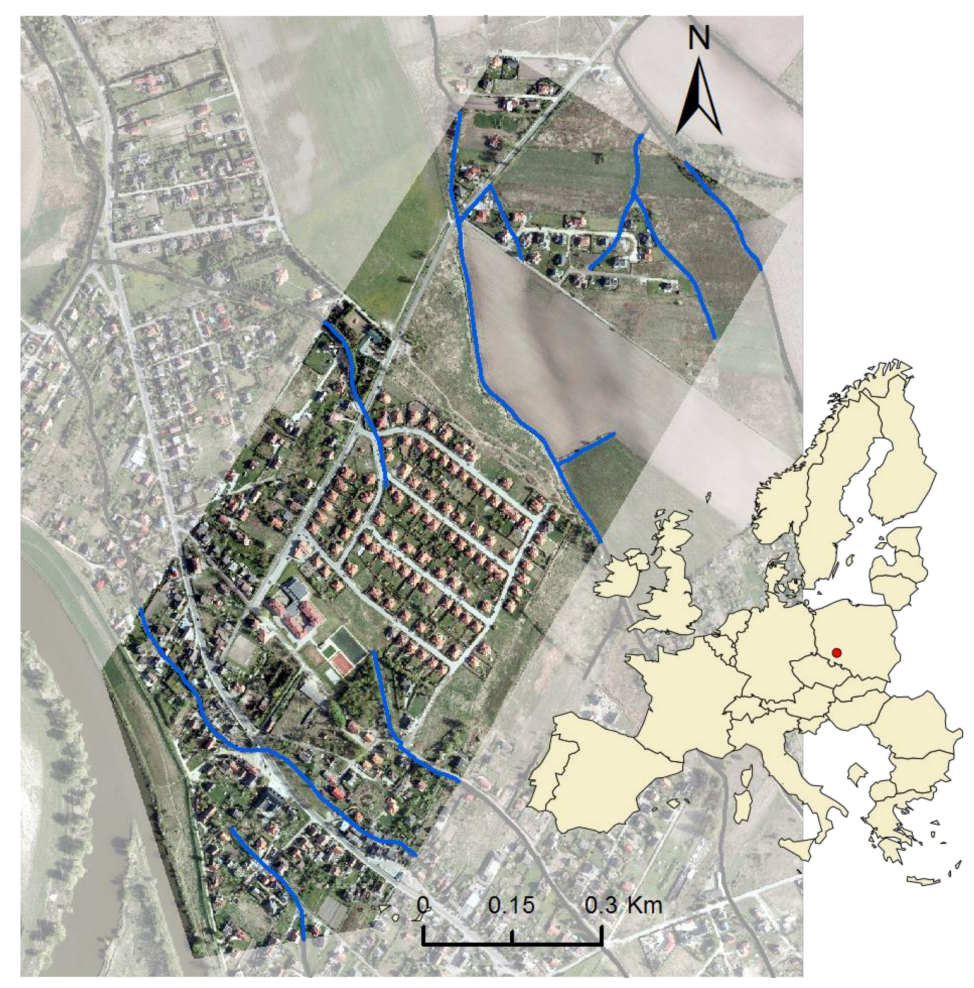

Figure 2. The study site in the village of Kamieniec Wrocławski. 
The southern part of the village is developed as a traditional discontinuous settlement, built up along the main road. A new housing area is located in the centre of the study site. The filed inspections showed some environmental aspects, typical for urban sprawl and unsustainable land development. The mean width of the inner road corridor is about $10.0 \mathrm{~m}$, so the pavement is used by inhabitants as parking places (Figure 3a). Rain run-off from impervious traffic lanes that gets collected by surface gutters is released directly to watercourse (Figure 3b). The rainwaters drained by an underground system are treated in the same way (Figure 3c). As a consequence, the flowing waters are polluted, and water-dependent ecosystems are degraded (Figure 3d). Rainwaters are not stored or recycled. There is no green or blue infrastructure in the study area in Kamieniec Wrocławski. Moreover, no technical facilities for the treatment of road rainwater are in place.

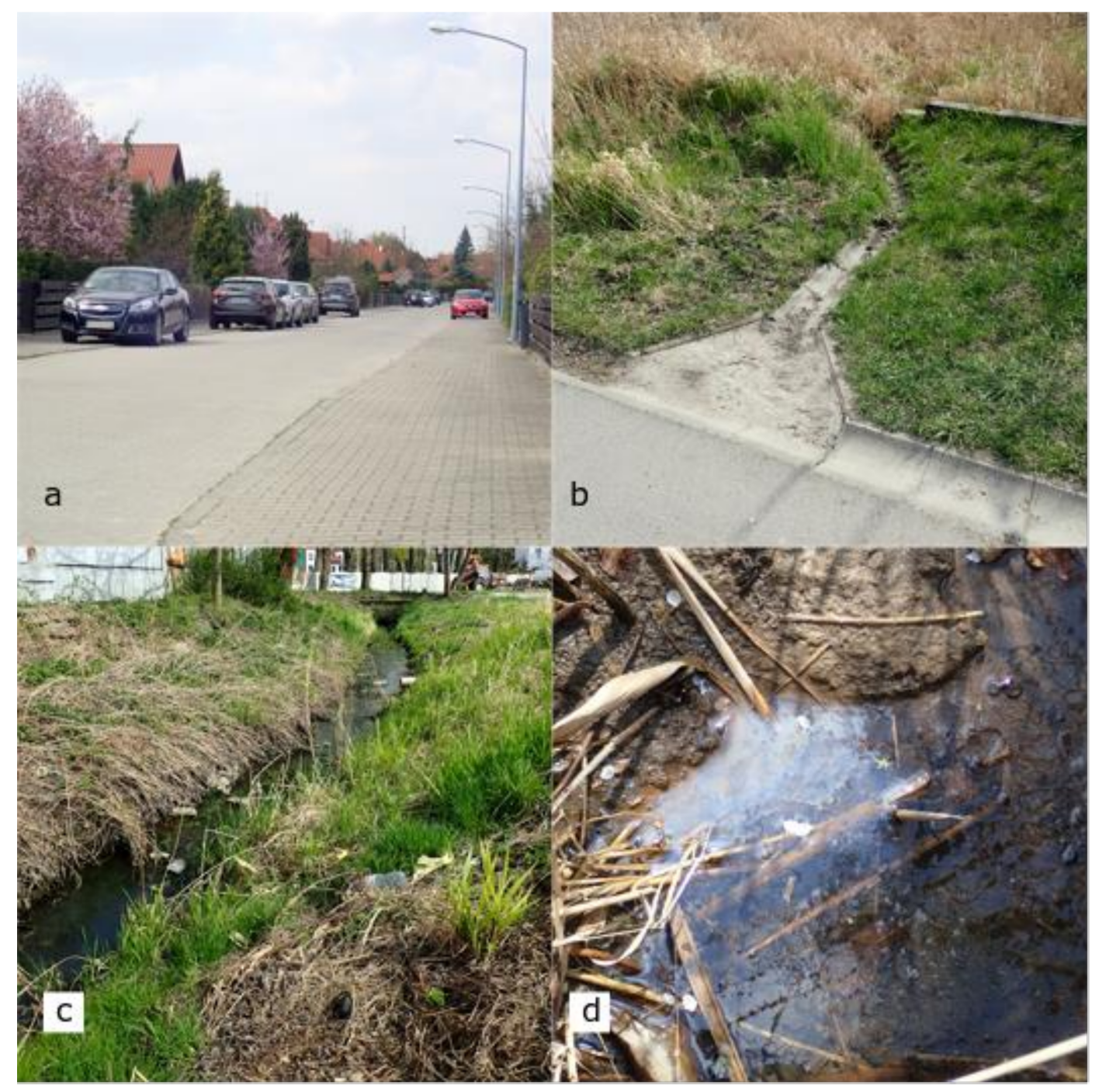

Figure 3. Environmental aspects of unsustainable land development (a) Soil sealing; (b) Run-off released to watercourse; (c) Drainage system outlet; (d) Water-dependent ecosystems degradation.

\subsection{Climate and Meteorological Conditions}

The pluvial and thermal conditions in the Wrocław agglomeration were described based on the climate dataset from the years 1981-2010.

The mean annual air temperature was $9.1^{\circ} \mathrm{C}$. The maximum daily air temperature was $37.4{ }^{\circ} \mathrm{C}$. The minimum record temperature was $-30.0^{\circ} \mathrm{C}$. The mean annual total precipitation was $536.9 \mathrm{~mm}$. The record daily precipitation was $115 \mathrm{~mm}$. The mean amount of monthly rainfall varied from 25.2 to 
$81.0 \mathrm{~mm}$. July remains the rainiest month. In 1997, when Wroclaw was affected by an extreme fluvial flood, the total annual precipitation reached $238.1 \mathrm{~mm}$.

The pluvial flooding simulations in this study were based on GFS meteorological forecast for period between 24 and 25 July 2017. The total forecast precipitation was $39.7 \mathrm{~mm}$, which would be almost $50 \%$ of the average total monthly rainfall. High rainfalls totals could be generated by cyclonic weather (Figure 4) and occurred during a frontal passage (Figure 5). The highest forecast rainfall rate was $13.6 \mathrm{~mm}$ per hour.

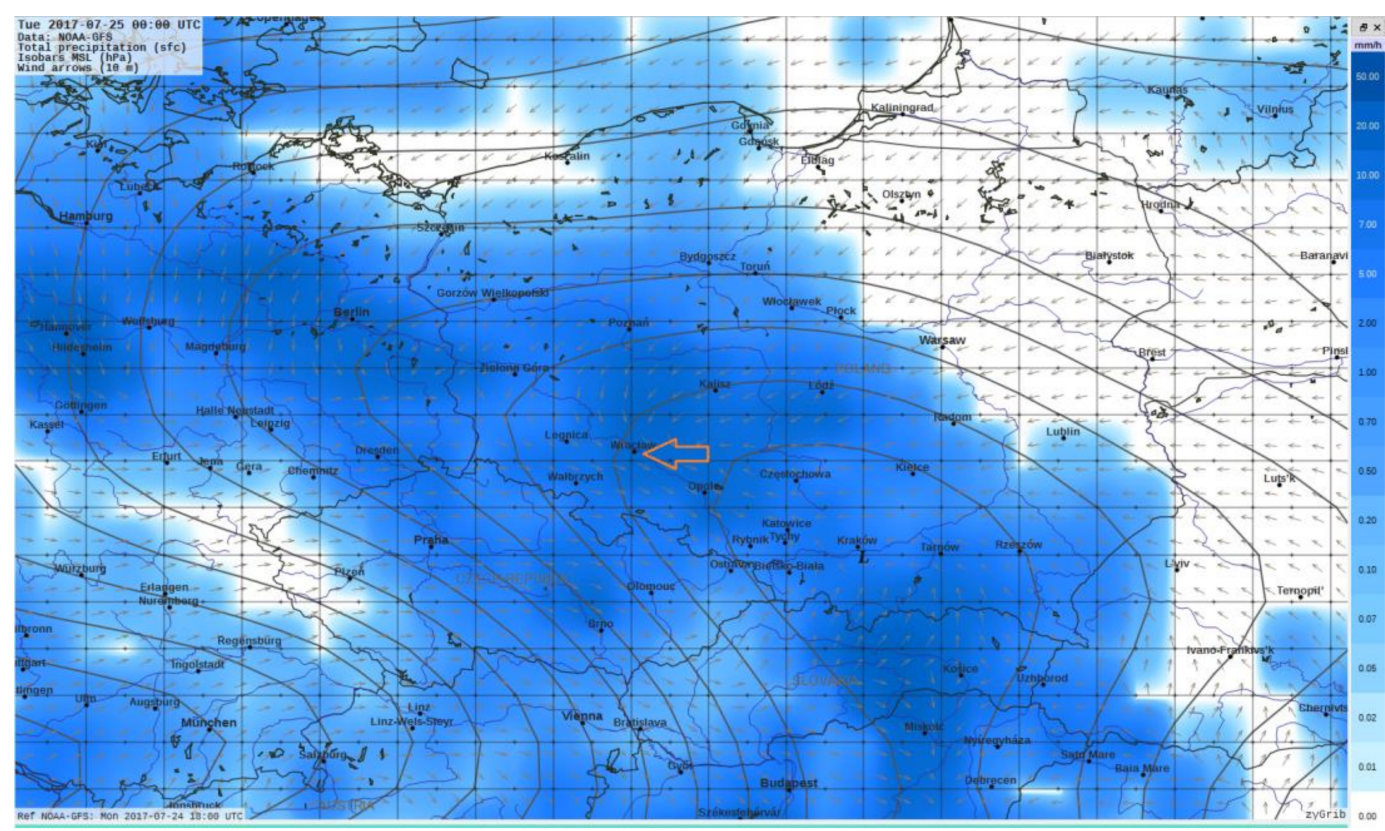

Figure 4. Weather map on 25 July 2017. Based on the GFS dataset, the center of low pressure is located in Southern Poland. The red arrow indicates the study site.

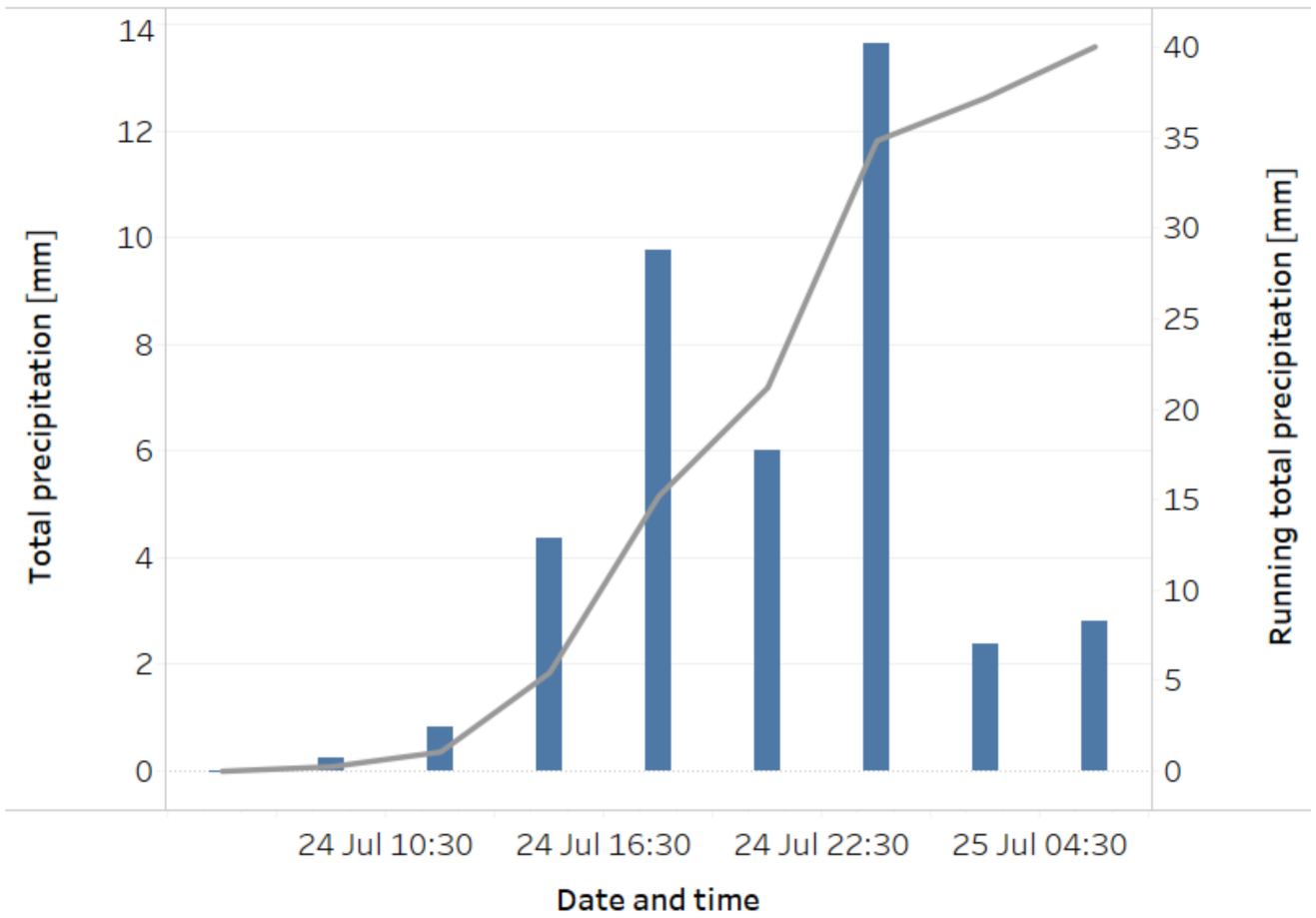

Figure 5. Forecast of weather conditions in study site from 24 to 25 July 2017 basing on GFS datasets. 


\section{Results: Simulations and Location Intelligence Tests}

The simulations provided during this research allowed for the assessment of the spatial distribution of pluvial flood risk (Figure 6a). The maximum risk score was 1.48 points. More than $4 \%$ of the road surfaces were classified by a risk of over 1.40 . The places which could be affected by rainwater impounding were located along the main road in the western and southern part of village, as well as in the new housing area in the eastern part. The vast majority of the roads $(90.1 \%)$ was not subjected by water impounding.

The pluvial flooding risk assessment allowed for the identification of the hydrologic sinks (Figure 6b). As the sinks collect and store the rainwater run-off, green or blue infrastructure could be located strictly in these places. We assumed that the microtopography of the road surfaces indicate the potential localisations of water management facilities.

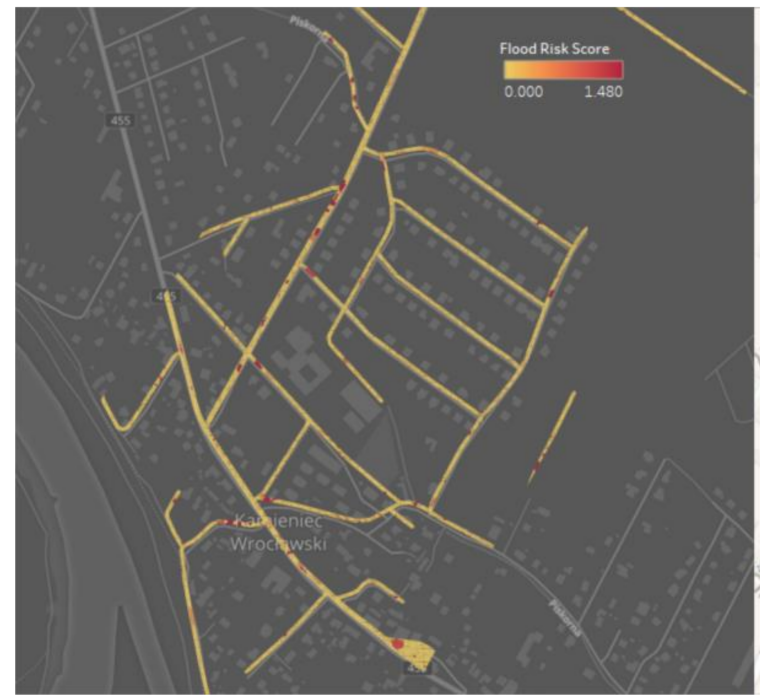

(a)

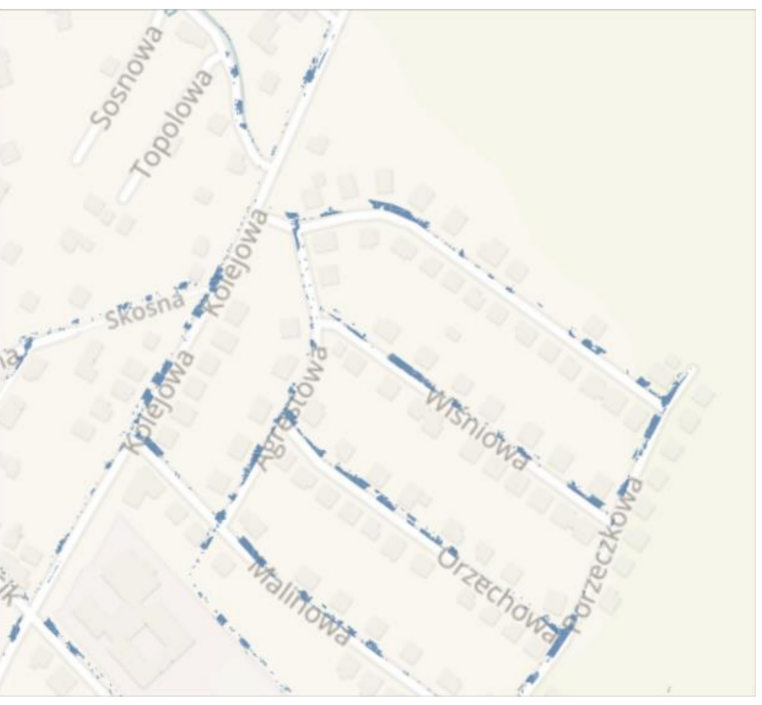

(b)

Figure 6. (a) Pluvial flood risk map; (b) Hydrologic sinks location (zoomed map).

The location intelligence system allowed for the calculation of the area of micro-watershed of the sinks. There are more than $2000 \mathrm{~m}^{2}$ of sinks with a flooding risk level surpassing 1.40. More than $2900 \mathrm{~m}^{2}$ are characterised by a risk level of 0.20 to 1.40 points. A combination of the area and effective rainfall gives the total volume of the road run-off, which could be captured by green or blue infrastructure.

The final analyses can be shown through the use of the location intelligence dashboard (Figure 7). This dashboard is an interactive decision support tool that combines all results of modelling. The system allows the determining and adjusting of acceptable risk levels, filtering land cover class, and using the spatial and temporal filtering. Finally, it calculates area and volume of run-off for selected sinks. The results were presented on the maps of the flooding risk, the sinks' locations, the pluvial conditions, and the total run-off charts. 


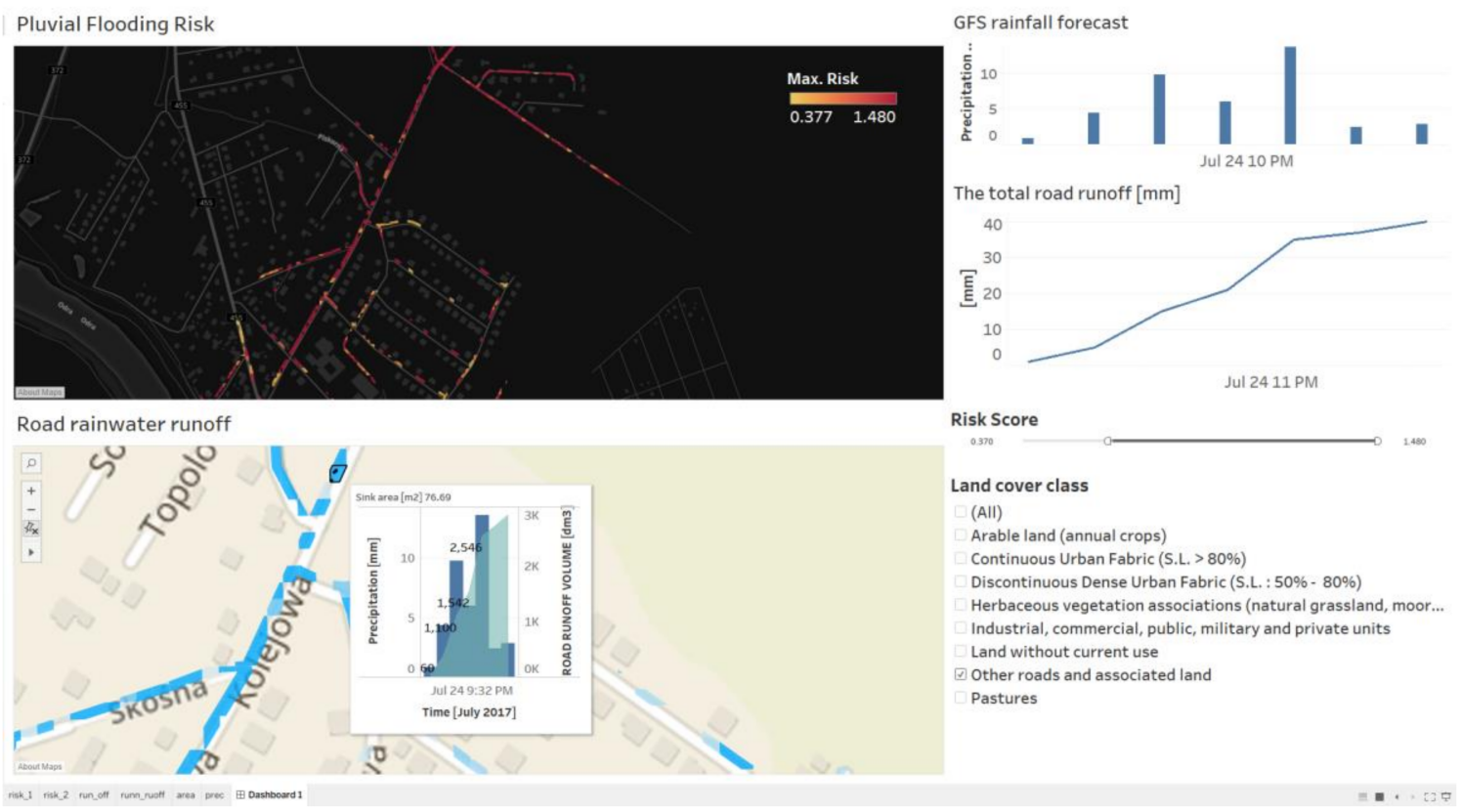

Figure 7. The location intelligence system's dashboard (screen capture).

During the tests, four potential locations were identified for the new GI. All sinks were located in places characterised by pluvial risk scores higher than 1.40 points. The total area of micro-watersheds was $79.1 \mathrm{~m}^{2}, 177.5 \mathrm{~m}^{2}, 191.6 \mathrm{~m}^{2}$, and $263.2 \mathrm{~m}^{2}$ for each of the four potential locations. Simulated run-off volumes during a pluvial event were $3077.5 \mathrm{dm}^{3}, 6905.8 \mathrm{dm}^{3}, 7454.4 \mathrm{dm}^{3}$, and 10,240.1 $\mathrm{dm}^{3}$, respectively. In these places, the devices improving the quality of rainwater discharged into natural basins should be located. At the stage of designing new road networks, the implementation of infiltration trenches should be incorporated in order to provide natural purification processes. In case the road network already exists, the problem of contamination of discharged rainwater can be solved by installing a GI supporting the treatment of precipitation. Among such solutions could be the design and construction of bioswales or rain gardens with hydrophyte filters. In case of the test area, there were locations enabling the use of the aforementioned solutions without the need to reconstruct the road system (Figure 3b). The use of GI solutions increases retention, improves the quality of discharged rain waters, as well as influences the aesthetic values of the environment in a positive manner.

\section{Conclusions and Future Work}

The main research purpose was to develop a location intelligence system that would support a pluvial flood risk assessment and the identification of water pollution sources from the roads. The developed interactive tool allowed for the adjustment of the risk level, the calculation of run-off volume, and the identification of the places where the water treatment facilities could be located. The intention was to develop the tool which could be used in existing built-up areas. The application of this location intelligence system could be helpful for the adaptation to climate change at the local level in an already developed country. Data were visualised as pluvial flood risk maps, sink locations, the total precipitation, and the total runoff charts. The location intelligence system has some limitations that should be overcome in future research and development efforts.

Due to many uncertainties and assumptions of risk calculations, the model should be used as a preliminary evaluation tool. The same approach was considered by Sperotto et al. [13]. At this moment, the model cannot be used to process data on an existing drainage systems and flow accumulation. The functionality of the system could be improved by incorporating information on water velocity, flow rate, and its erosivity. Uncertainties concerning the soil and surface hydraulic parameters are 
among the challenges for future work and extension of the model. Proper hydraulic modelling is essential for a valid pluvial risk assessment and should be based on the high quality Urban Atlas and the accurate high resolution rainfall distribution [7,94]. Although the model incorporated LiDAR data into the modelling, the rainfall information was taken from the low-resolution GFS datasets. Based on the research results, it was decided to enhance the system by weather radar data processing. This should increase the accuracy of the spatial analyses significantly. At this moment the possibilities of using the 'wradlib' open source library are being examined [95].

At this stage, the location intelligence system is not able to model the transportation of pollutants. The core element of the PFRA tool was originally designed as a planning support tool, which simulates the water impounding in depressions in a certain a terrain. PFRA is an original script and can therefore be combined with any spatial model. As the storm run-off quality depends on the traffic density, in future research, the identification of storm water pollutant sources from roads will be enriched by real-time traffic monitoring or traffic modelling component with use of graph theory [67]. PFRA also needs to be enriched by flow accumulation modelling.

The results of the tests showed that the pluvial flood risk scoring should be more adjustable. At this stage, the maximum risk score is representative for the rainfalls amount of $400 \mathrm{~mm}$. There are plans to modify the script in the near future so that the maximum risk level is to be a used as a parameter in decision-making.

The most significant problems relate to the technical and computational limitations. Geospatial analyses are mainly based on layer intersections; these analyses produce many spatial data. As geodatabases can store up to two billion number of records in the tables, the studied area needs to be divided into smaller parts. GIS modelling should be conducted separately for each subarea. Separate modelling results can be easily re-joined within a location intelligence system, which includes a BI tool. As Tableau is originally designed to operate using big data databases, it allows for effective analyses and data exploration. A detailed dissection on technical aspects of PFRA functioning is given by Szewrański et al. [65].

According to the limitations outlined above, the intelligence system can be used as an indicator-based planning support tool for the localisation of the surface water treatment and small retention systems. It can be used as a scenario-based decision support system for local development, which enables the identification of the environmental risk assessment of a specific weather event before its occurrence.

The main findings of this study are that a location intelligence system can effectively identify the spatial and temporal distribution of pluvial flood risks, can be used to evaluate the total run-off from the roads, and can help localise potential places of new water management infrastructure.

Author Contributions: The article was drafted by all authors. Data curation, S.S., J.C. and M.Ś.; Investigation, J.K. and M.S.; Methodology, S.S., J.C., J.v.H., J.K., K.T.-D. and R.Ż.; Software, S.S. and J.C.; Supervision, K.T.-D. and R.Ż.; Visualisation, S.S.; Writing-original draft, S.S.; Writing-review \& editing, J.v.H. and J.K. S.S. is the corresponding author, the subsequent names are given in alphabetical order.

Acknowledgments: Land Cover data: European Union, Copernicus Land Monitoring Service 2018, European Environment Agency (EEA) [https://land.copernicus.eu/local/urban-atlas]. GFS datasets were retrieved from the repository of the National Centers for Environmental Prediction (NCEP) [https:/ / www.ncdc.noaa.gov/dataaccess/model-data/model-datasets/global-forcast-system-gfs]. Regional Climatic data were obtained from the Institute of Meteorology and Water Management-National Research Institute [http://www.pogodynka.pl/ polska/daneklimatyczne].

Conflicts of Interest: The authors declare no conflict of interest.

\section{References}

1. Astaraie-Imani, M.; Kapelan, Z.; Fu, G.; Butler, D. Assessing the combined effects of urbanisation and climate change on the river water quality in an integrated urban wastewater system in the UK. J. Environ. Manag. 2012, 112, 1-9. [CrossRef] [PubMed] 
2. Couch, C.; Petschel-Held, G.; Leontidou, L. Urban Sprawl in Europe: Landscape, Land-Use Change and Policy; Wiley: Hoboken, NJ, USA, 2008.

3. Haase, D.; Kabisch, N.; Haase, A. Endless Urban Growth? On the Mismatch of Population, Household and Urban Land Area Growth and Its Effects on the Urban Debate. PLoS ONE 2013, 8, e66531. [CrossRef] [PubMed]

4. Triantakonstantis, D.; Stathakis, D. Examining urban sprawl in Europe using spatial metrics. Geocarto Int. 2015, 30, 1092-1112. [CrossRef]

5. Recanatesi, F.; Petroselli, A.; Ripa, M.N.; Leone, A. Assessment of stormwater runoff management practices and BMPs under soil sealing: A study case in a peri-urban watershed of the metropolitan area of Rome (Italy). J. Environ. Manag. 2017, 201, 6-18. [CrossRef] [PubMed]

6. Mahbub, P.; Ayoko, G.A.; Goonetilleke, A.; Egodawatta, P.; Kokot, S. Impacts of Traffic and Rainfall Characteristics on Heavy Metals Build-up and Wash-off from Urban Roads. Environ. Sci. Technol. 2010, 44, 8904-8910. [CrossRef] [PubMed]

7. Apel, H.; Trepat, O.M.; Hung, N.N.; Chinh, D.T.; Merz, B.; Dung, N.V. Combined fluvial and pluvial urban flood hazard analysis: Concept development and application to Can Tho city, Mekong Delta, Vietnam. Nat. Hazards Earth Syst. Sci. 2016, 16, 941-961. [CrossRef]

8. Chen, Y.; Samuelson, H.W.; Tong, Z. Integrated design workflow and a new tool for urban rainwater management. J. Environ. Manag. 2016, 180, 45-51. [CrossRef] [PubMed]

9. Willems, P.; Arnbjerg-Nielsen, K.; Olsson, J.; Nguyen, V.T. Climate change impact assessment on urban rainfall extremes and urban drainage: Methods and shortcomings. Atmos. Res. 2012, 103, 106-118. [CrossRef]

10. Olsen, A.S.; Zhou, Q.; Linde, J.J.; Arnbjerg-Nielsen, K. Comparing methods of calculating expected annual damage in urban pluvial flood risk assessments. Water 2015, 7, 255-270. [CrossRef]

11. Guerreiro, S.; Glenis, V.; Dawson, R.; Kilsby, C. Pluvial Flooding in European Cities-A Continental Approach to Urban Flood Modelling. Water 2017, 9, 296. [CrossRef]

12. Qin, H.; Li, Z.; Fu, G. The effects of low impact development on urban flooding under different rainfall characteristics. J. Environ. Manag. 2013, 129, 577-585. [CrossRef] [PubMed]

13. Sperotto, A.; Torresan, S.; Gallina, V.; Coppola, E.; Critto, A.; Marcomini, A. A multi-disciplinary approach to evaluate pluvial floods risk under changing climate: The case study of the municipality of Venice (Italy). Sci. Total Environ. 2016, 562, 1031-1043. [CrossRef] [PubMed]

14. Zhou, Z.N.; Qu, L.; Zou, T. Quantitative Analysis of Urban Pluvial Flood Alleviation by Open Surface Water Systems in New Towns: Comparing Almere and Tianjin Eco-City. Sustainability 2015, 7, 13378-13398. [CrossRef]

15. Bhattarai, R.; Yoshimura, K.; Seto, S.; Nakamura, S.; Oki, T. Statistical model for economic damage from pluvial floods in Japan using rainfall data and socioeconomic parameters. Nat. Hazards Earth Syst. Sci. 2016, 16, 1063-1077. [CrossRef]

16. Van Ootegem, L.; Verhofstadt, E.; Van Herck, K.; Creten, T. Multivariate pluvial flood damage models. Environ. Impact Assess. Rev. 2015, 54, 91-100. [CrossRef]

17. Grahn, T.; Nyberg, L. Assessment of pluvial flood exposure and vulnerability of residential areas. Int. J. Disaster Risk Reduct. 2017, 21, 367-375. [CrossRef]

18. Blanc, J.; Hall, J.W.; Roche, N.; Dawson, R.J.; Cesses, Y.; Burton, A.; Kilsby, C.G. Enhanced efficiency of pluvial flood risk estimation in urban areas using spatial-temporal rainfall simulations. J. Flood Risk Manag. 2012, 5, 143-152. [CrossRef]

19. Hammond, M.J.; Chen, A.S.; Djordjević, S.; Butler, D.; Mark, O. Urban flood impact assessment: A state-of-the-art review. Urban Water J. 2015, 12, 14-29. [CrossRef]

20. Nguyen, H.Q.; Radhakrishnan, M.; Huynh, T.T.N.; Baino-Salingay, M.L.; Ho, L.P.; Van der Steen, P.; Pathirana, A. Water Quality Dynamics of Urban Water Bodies during Flooding in Can Tho City, Vietnam. Water 2017, 9, 260. [CrossRef]

21. Kim, H.; Jeong, H.; Jeon, J.; Bae, S. The Impact of Impervious Surface on Water Quality and Its Threshold in Korea. Water 2016, 8, 111. [CrossRef]

22. Chen, L.; Zhi, X.; Shen, Z.; Dai, Y.; Aini, G. Comparison between snowmelt-runoff and rainfall-runoff nonpoint source pollution in a typical urban catchment in Beijing, China. Environ. Sci. Pollut. Res. Int. 2018, 25, 2377-2388. [CrossRef] [PubMed] 
23. Morgan, D.; Johnston, P.; Osei, K.; Gill, L. Sediment build-up on roads and footpaths of a residential area. Urban Water J. 2017, 14, 378-385. [CrossRef]

24. Zhao, H.; Chen, X.; Hao, S.; Jiang, Y.; Zhao, J.; Zou, C.; Xie, W. Is the wash-off process of road-deposited sediment source limited or transport limited? Sci. Total Environ. 2016, 563-564, 62-70. [CrossRef] [PubMed]

25. Zafra, C.; Temprano, J.; Suarez, J. A simplified method for determining potential heavy metal loads washed-off by stormwater runoff from road-deposited sediments. Sci. Total Environ. 2017, 601-602, 260-270. [CrossRef] [PubMed]

26. Liu, A.; Li, D.Z.; Liu, L.; Guan, Y.T. Understanding the Role of Urban Road Surface Characteristics in influencing Stormwater Quality. Water Resour. Manag. 2014, 28, 5217-5229. [CrossRef]

27. Fraga, I.; Charters, F.J.; O'Sullivan, A.D.; Cochrane, T.A. A novel modelling framework to prioritize estimation of non-point source pollution parameters for quantifying pollutant origin and discharge in urban catchments. J. Environ. Manag. 2016, 167, 75-84. [CrossRef] [PubMed]

28. Jartun, M.; Ottesen, R.T.; Steinnes, E.; Volden, T. Runoff of particle bound pollutants from urban impervious surfaces studied by analysis of sediments from stormwater traps. Sci. Total Environ. 2008, 396, 147-163. [CrossRef] [PubMed]

29. Klimaszewska, K.; Polkowska, Ż.; Namieśnik, J. Influence of Mobile Sources on Pollution of Runoff Waters from Roads with High Traffic Intensity. Pol. J. Environ. Stud. 2007, 16, 889-897.

30. Markiewicz, A.; Bjorklund, K.; Eriksson, E.; Kalmykova, Y.; Stromvall, A.M.; Siopi, A. Emissions of organic pollutants from traffic and roads: Priority pollutants selection and substance flow analysis. Sci. Total Environ. 2017, 580, 1162-1174. [CrossRef] [PubMed]

31. Zhang, Y.; Sun, T.T.; Li, F.Y.; Wang, J.L.; Oh, K. Effect of decing salts on ion concentrations in urban stormwater runoff. Int. Symp. Environ. Sci. Technol. 2013, 18, 567-571. [CrossRef]

32. Chow, M.F.; Yusop, Z.; Shirazi, S.M. Storm runoff quality and pollutant loading from commercial, residential, and industrial catchments in the tropic. Environ. Monit. Assess. 2013, 185, 8321-8331. [CrossRef] [PubMed]

33. Kayhanian, M.; Fruchtman, B.D.; Gulliver, J.S.; Montanaro, C.; Ranieri, E.; Wuertz, S. Review of highway runoff characteristics: Comparative analysis and universal implications. Water Res. 2012, 46, 6609-6624. [CrossRef] [PubMed]

34. Berndtsson, J.C. Storm water quality of first flush urban runoff in relation to different traffic characteristics. Urban Water J. 2014, 11, 284-296. [CrossRef]

35. Fronczyk, J.; Radziemska, M.; Dynowski, P.; Mazur, Z.; Bazydlo, M. Quality of Water in the Road Drainage Systems in the Warsaw Agglomeration, Poland. Water 2016, 8, 429. [CrossRef]

36. Galfi, H.; Osterlund, H.; Marsalek, J.; Viklander, M. Mineral and Anthropogenic Indicator Inorganics in Urban Stormwater and Snowmelt Runoff: Sources and Mobility Patterns. Water Air Soil Pollut. 2017, 228, 263. [CrossRef] [PubMed]

37. Kayhanian, M.; McKenzie, E.R.; Leatherbarrow, J.E.; Young, T.M. Characteristics of road sediment fractionated particles captured from paved surfaces, surface run-off and detention basins. Sci. Total Environ. 2012, 439, 172-186. [CrossRef] [PubMed]

38. Chen, R.H.; Li, F.P.; Zhang, H.P.; Jiang, Y.; Mao, L.C.; Wu, L.L.; Chen, L. Comparative analysis of water quality and toxicity assessment methods for urban highway runoff. Sci. Total Environ. 2016, 553, 519-523. [CrossRef] [PubMed]

39. Gillis, P.L. Cumulative impacts of urban runoff and municipal wastewater effluents on wild freshwater mussels (Lasmigona costata). Sci. Total Environ. 2012, 431, 348-356. [CrossRef] [PubMed]

40. Olofsson, B.; Rasul, H.; Lundmark, A. Spread of Water-Borne Pollutants at Traffic Accidents on Roads. Water Air Soil Pollut. 2017, 228, 323. [CrossRef] [PubMed]

41. Rozer, V.; Muller, M.; Bubeck, P.; Kienzler, S.; Thieken, A.; Pech, I.; Schroter, K.; Buchholz, O.; Kreibich, H. Coping with Pluvial Floods by Private Households. Water 2016, 8, 304. [CrossRef]

42. Simões, N.E.; Ochoa-Rodríguez, S.; Wang, L.P.; Pina, R.D.; Marques, A.S.; Onof, C.; Leitão, J.P. Stochastic urban pluvial flood hazard maps based upon a spatial-temporal rainfall generator. Water 2015, 7, 3396-3406. [CrossRef]

43. Serre, D.; Barroca, B.; Diab, Y. Urban flood mitigation: Sustainable options. In Sustainable City Vi: Urban Regeneration and Sustainability; Brebbia, C.A., Hernandez, S., Tiezzi, E., Eds.; WIT Press: Ashurst, UK, 2010; Volume 129, pp. 299-309. ISBN 978-1-84564-432-1. 
44. Sun, S.; Djordjević, S.; Khu, S.-T. A general framework for flood risk-based storm sewer network design. Urban Water J. 2011, 8, 13-27. [CrossRef]

45. Ferreira, C.S.S.; Walsh, R.P.D.; Costa, M.D.; Coelho, C.O.A.; Ferreira, A.J.D. Dynamics of surface water quality driven by distinct urbanization patterns and storms in a Portuguese peri-urban catchment. J. Soils Sediments 2016, 16, 2606-2621. [CrossRef]

46. Gunawardena, J.; Ziyath, A.M.; Egodawatta, P.; Ayoko, G.A.; Goonetilleke, A. Sources and transport pathways of common heavy metals to urban road surfaces. Ecol. Eng. 2015, 77, 98-102. [CrossRef]

47. Maniquiz-Redillas, M.C.; Kim, L.H. Evaluation of the capability of low-impact development practices for the removal of heavy metal from urban stormwater runoff. Environ. Technol. 2016, 37, 2265-2272. [CrossRef] [PubMed]

48. Burszta-Adamiak, E. Analysis of Stormwater Retention on Green Roofs/Badania Retencji Wód Opadowych Na Dachach Zielonych. Arch. Environ. Prot. 2012, 38, 3-13. [CrossRef]

49. Ahiablame, L.; Shakya, R. Modeling flood reduction effects of low impact development at a watershed scale. J. Environ. Manag. 2016, 171, 81-91. [CrossRef] [PubMed]

50. Lejcuś, K.; Śpitalniak, M.; Dabrowska, J. Swelling Behaviour of Superabsorbent Polymers for Soil Amendment under Different Loads. Polymers 2018, 10, 271. [CrossRef]

51. Bawiec, A. Efficiency of nitrogen and phosphorus compounds removal in hydroponic wastewater treatment plant. Environ. Technol. 2018, 1-11. [CrossRef] [PubMed]

52. Pawęska, K.; Bawiec, A.; Pulikowski, K. Wastewater treatment in submerged aerated biofilter under condition of high ammonium concentration. Ecol. Chem. Eng. S 2017, 24, 431-442. [CrossRef]

53. Paruch, L.; Paruch, A.M.; Blankenberg, A.-G.B.; Haarstad, K.; Mæhlum, T. Norwegian study on microbial source tracking for water quality control and pollution removal in constructed wetland treating catchment run-off. Water Sci. Technol. 2017, 76, 1158-1166. [CrossRef] [PubMed]

54. Laks, I.; Sojka, M.; Walczak, Z.; Wróżyński, R. Possibilities of Using Low Quality Digital Elevation Models of Floodplains in Hydraulic Numerical Models. Water 2017, 9, 283. [CrossRef]

55. Walczak, Z.; Sojka, M.; Wróżyński, R.; Laks, I. Estimation of Polder Retention Capacity Based on ASTER, SRTM and LIDAR DEMs: The Case of Majdany Polder (West Poland). Water 2016, 8, 230. [CrossRef]

56. Wang, T.; Han, Q.; de Vries, B. A semi-automatic neighborhood rule discovery approach. Appl. Geogr. 2017, 88, 73-83. [CrossRef]

57. Kazak, J.; Świąder, M.; Szewrański, S.; Żmuda, R. Geo-environmental indicators in Strategic Environmental Assessment. Acta Sci. Pol. Form. Circumiectus 2017, 16, 123-135. [CrossRef]

58. Trogu, D.; Campagna, M. Towards Spatial Composite Indicators: A Case Study on Sardinian Landscape. Sustainability 2018, 10, 1369. [CrossRef]

59. Yin, J.; Yu, D.; Yin, Z.; Liu, M.; He, Q. Evaluating the impact and risk of pluvial flash flood on intra-urban road network: A case study in the city center of Shanghai, China. J. Hydrol. 2016, 537, 138-145. [CrossRef]

60. Fallah Shorshani, M.; Bonhomme, C.; Petrucci, G.; Andre, M.; Seigneur, C. Road traffic impact on urban water quality: A step towards integrated traffic, air and stormwater modelling. Environ. Sci. Pollut. Res. Int. 2014, 21, 5297-5310. [CrossRef] [PubMed]

61. Gong, Y.W.; Liang, X.Y.; Li, X.N.; Li, J.Q.; Fang, X.; Song, R.N. Influence of Rainfall Characteristics on Total Suspended Solids in Urban Runoff: A Case Study in Beijing, China. Water 2016, 8, 278. [CrossRef]

62. Chen, P.-Y.; Tung, C.-P.; Li, Y.-H. Low Impact Development Planning and Adaptation Decision-Making under Climate Change for a Community against Pluvial Flooding. Water 2017, 9, 756. [CrossRef]

63. Trenouth, W.R.; Gharabaghi, B. Highway runoff quality models for the protection of environmentally sensitive areas. J. Hydrol. 2016, 542, 143-155. [CrossRef]

64. Bertsch, R.; Glenis, V.; Kilsby, C. Urban Flood Simulation Using Synthetic Storm Drain Networks. Water 2017, 9, 925. [CrossRef]

65. Szewrański, S.; Chruściński, J.; Kazak, J.; Świąder, M.; Tokarczyk-Dorociak, K.; Żmuda, R. Pluvial Flood Risk Assessment Tool (PFRA) for Rainwater Management and Adaptation to Climate Change in Newly Urbanised Areas. Water 2018, 10, 386. [CrossRef]

66. Szewrański, S.; Kazak, J.; Sylla, M.; Świąder, M. Spatial Data Analysis with the Use of ArcGIS and Tableau Systems. In The Rise of Big Spatial Data; Springer: Berlin, Germany, 2016.

67. Kazak, J.; Chalfen, M.; Kamińska, J.; Szewrański, S.; Świąder, M. Geo-Dynamic Decision Support System for Urban Traffic Management. In Dynamics in GIscience; Springer: Berlin, Germany, 2018; pp. 195-207. 
68. NRCS (Natural Resources Conservation Service). Urban Hydrology for Small Watersheds TR-55; United States Department of Agriculture Natural resource conservation Service: Washington, DC, USA, 1986.

69. Walega, A.; Cupak, A.; Amatya, D.M.; Drozdzal, E. Comparison of direct outflow calculated by modified SCS-CN methods for mountainous and highland catchments in Upper Vistula basin, Poland and lowland catchment in South Carolina, U.S.A. Acta Sci. Pol. Circumiectus 2017, 16, 187-207. [CrossRef]

70. Ignar, S. Metoda SCS i jej Zastosowanie do Wyznaczania Opadu Efektywnego. Przegląd Geofiz. 1988, XXXIII, 451-455. (In Polish)

71. Przybyła, K.; Kulczyk-Dynowska, A.; Kachniarz, M. Quality of life in the regional capitals of Poland. J. Econ. Issues 2014, 48, 181-196. [CrossRef]

72. Szewrański, S.; Kazak, J.; Żmuda, R.; Wawer, R. Indicator-Based Assessment for Soil Resource Management in the Wrocław Larger Urban Zone of Poland. Pol. J. Environ. Stud. 2017, 26, 2239-2248. [CrossRef]

73. Hełdak, M.; Raszka, B. Evaluation of the spatial policy of a commune with regard to planned land use. Pol. J. Environ. Stud. 2013, 22, 125-130.

74. Świąder, M.; Szewrański, S.; Kazak, J. Foodshed as an Example of Preliminary Research for Conducting Environmental Carrying Capacity Analysis. Sustainability 2018, 10, 882. [CrossRef]

75. Solecka, I.; Sylla, M.; Świąder, M. Urban Sprawl Impact on Farmland Conversion in Suburban Area of Wroclaw, Poland. IOP Conf. Ser. Mater. Sci. Eng. 2017, 245, 72002. [CrossRef]

76. Tokarczyk-Dorociak, K.; Kazak, J.; Szewrański, S. The impact of a big city on land use in suburban area-the case of Wrocław (Poland). J. Ecol. Eng. 2018, 19, 89-98. [CrossRef]

77. Krajewski, P.; Solecka, I. Barbara-Mastalska-Cetera Landscape Change Index as a Tool for Spatial Analysis. IOP Conf. Ser. Mater. Sci. Eng. 2017, 245, 072014. [CrossRef]

78. Kamińska, J.A. The use of random forests in modelling short-term air pollution effects based on traffic and meteorological conditions: A case study in Wrocław. J. Environ. Manag. 2018, 217, 164-174. [CrossRef] [PubMed]

79. Pachurka, Ł.; Rogula-Kozłowska, W.; Chlebowska-Styś, A.; Nych, A.; Zwoździak, A. Exposure of urban agglomeration population to the selected components of $\mathrm{PM}_{1}$ emitted from low emission sources. E3S Web Conf. 2017, 17, 00071. [CrossRef]

80. Sobczyk, K.; Hołtra, A. The Content of Heavy Metals (Cu, Zn, Cr, Ni, Pb) in the Soil Near the Arterial Roads in Wroclaw (Poland). E3S Web Conf. 2017, 17, 00083. [CrossRef]

81. Sylla, M. Mapping and assessment of the potential to supply selected ecosystem services at a sub-regional scale. The example of Wroclaw and its surrounding municipalities. Ekon. i Środowisko 2016, 4, 87-98.

82. Kalbarczyk, R.; Sobolewski, R.; Kalbarczyk, E. Assessment of human thermal sensations based on bioclimatic indices in a suburban population, Wrocław (SW Poland). Pol. J. Natl. Sci. 2015, 30, 185-201.

83. Kalbarczyk, R.; Kalbarczyk, R.; Sobolewski, R.; Kalbarczyk, E. Biometeorological determinants of the tropospheric ozone concentration in the suburban conditions of Wroclaw, Poland. J. Elemntol. 2012, 21, 729-744. [CrossRef]

84. Hełdak, M.; Płuciennik, M. Costs of Urbanisation in Poland, Based on the Example of Wrocław. IOP Conf. Ser. Mater. Sci. Eng. 2017, 245, 72003. [CrossRef]

85. Kajdanek, K. Newcomers vs. old-timers? Community, cooperation and conflict in the post-socialist suburbs of Wroclaw, Poland. In Mobilities and Neighbourhood Belonging in Cities and Suburbs; Palgrave Macmillan: Basingstoke, UK, 2014; pp. 182-199.

86. Piepiora, Z.; Kachniarz, M.; Babczuk, A. Financing the Counteraction of Natural Disasters' Effects in Lower Silesian Voivodeship. In Proceedings of the 2015 International Conference on Management Engineering and Management Innovation, Changsha, China, 10-11 January 2015; Wang, M., Ed.; Atlantis Press: Paris, France, 2015; Volume 3, pp. 215-220.

87. Rucinska, D. Spatial Distribution of Flood Risk and Quality of Spatial Management: Case Study in Odra Valley, Poland. Risk Anal. 2015, 35, 241-251. [CrossRef] [PubMed]

88. Kundzewicz, Z.W.; Szamalek, K.; Kowalczak, P. The great flood of 1997 in Poland. Hydrol. Sci. J. 1999, 44, 855-870. [CrossRef]

89. Tokarczyk-Dorociak, K.; Walter, E.; Kobierska, K.; Kołodynski, R. Rainwater management in the urban landscape of Wroclaw in terms of adaptation to climate changes. J. Ecol. Eng. 2017, 18, 171-184. [CrossRef]

90. Szewrański, S.; Kazak, J.; Szkaradkiewicz, M.; Sasik, J. Flood risk factors in suburban area in the context of climate change adaptation policies-Case study of Wroclaw, Poland. J. Ecol. Eng. 2015. [CrossRef] 
91. Kiełkowska, J.; Tokarczyk-Dorociak, K.; Kazak, J.; Szewrański, S.; van Hoof, J. Urban Adaptation to Climate Change Plans and Policies-the Conceptual Framework of a Methodological Approach. J. Ecol. Eng. 2018, 19, 50-62. [CrossRef]

92. Kazak, J.K. The use of a decision support system for sustainable urbanization and thermal comfort in adaptation to climate change actions-the case of the Wroclaw Larger Urban Zone (Poland). Sustainability 2018, 10, 1083. [CrossRef]

93. Kazak, J.; van Hoof, J.; Szewrański, S. Challenges in the wind turbines location process in Central Europe-The use of spatial decision support systems. Renew. Sustain. Energy Rev. 2017. [CrossRef]

94. Scheid, C.; Schmitt, T.G.; Bischoff, G.; Hüffmeyer, N.; Krieger, K.; Waldhoff, A.; Günner, C. GIS-based methodology for pluvial flood risk analysis in Hamburg. In Proceedings of the International Conference Novatech, Lyon, France, 23-27 June 2013; pp. 23-27.

95. Heistermann, M.; Jacobi, S.; Pfaff, T. Technical Note: An open source library for processing weather radar data wradlib. Hydrol. Earth Syst. Sci. 2013, 17, 863-871. [CrossRef]

(c) 2018 by the authors. Licensee MDPI, Basel, Switzerland. This article is an open access article distributed under the terms and conditions of the Creative Commons Attribution (CC BY) license (http:// creativecommons.org/licenses/by/4.0/). 